\title{
Causative Factors of Downturn in Growth and Performance of Stock Markets in Pakistan
}

\author{
Kehar Khan Khoso
}

\begin{abstract}
In any economy, the stock market plays an important role by mobilizing domestic resources and channeling them toward productive investment. This implies that it has a significant relationship with the economy. The stock market has been a great source to earn profit not only for companies but also for the individuals. The present research examines the relationship between stock markets and the factors that affect the growth and performance of the capital markets. The research has concluded that political instability and uncertainty, terrorism and inadequate government policies highly influence the performance of stock markets, causing volatility in the economy. Besides, these factors keep foreign investors to stay away or withdraw their investments from stock markets. However, the sustainable political stability, long term government policies, strict vigilance by the market regulators, tight security measures, effective counterterrorism tools and techniques and collective wisdom can help to resolve the forgoing issues and assist country's stock markets to grow beyond expectations.
\end{abstract}

Keywords: Stock market, growth, performance, causative factors, terrorism, government policies.

\section{Introduction}

Stock Market is actually a mechanism which enables the companies to trade their stocks or securities etc. People who invest through stock markets/stock exchanges belong to different categories (i.e. governments, large fund traders and small individual investors). There is no denying the fact that huge income inequalities are being reduced by the stock markets because many people find the opportunity to participate as owners in others' business. That is the reason which compels companies to develop their organizational values and standards. According to one analyst, efficiency and effectiveness is the only way to attract the attention of stock holders. It is a common belief that normally public companies follow the well management standards and procedure rather than that of the private companies. This way, redistribution of wealth takes place in the market called 'stock exchange'.

Stock exchange is a corporation or mutual organization which provides facilities for stock brokers to trade company stocks and other securities through the stock exchange. Along with this, stock exchanges also provide facilities for issue and sell of securities and other financial instruments and capital events including the payment of income and dividends. According to E. Victor and W.A Thomas (2003), "Stock exchange plays a

Kehar Khan Khoso is the Deputy Director (HR), University of Balochistan, dd.hr@uob.edu.pk

Journal of Independent Studies and Research - MSSE

Volume 9

Number 1

\begin{tabular}{l|l} 
January 2011 & 145
\end{tabular} 
vital role in the economy of any country. It works as the backbone of the country's economy. The stock exchange facilitates companies to raise capital for expansion through selling/floating shares to the investing public".

"The Karachi Stock Exchange, which is the premier stock exchange of Pakistan, was established on September 18, 1947. Initially, it started with five companies and paidup capital of Rs. 37 million. Presently, The Karachi Stock Exchange is owned by 200 members with 651 listed companies and listed capital of $\$ 9.65$ billion. Today, KSE is the largest and most liquid stock exchange of the country, having four indices- KSE100, KSE-30, KSE All and KMI-30" (www.kse.com.pk).

People want their life long savings to be secure and earn profit in order to satisfy their needs. Therefore they invest their money in physical business. But when there is no conducive environment for such physical business, people turn to Stocks, gold and property business assuming these channels as safe nets.

\subsection{Background of the Study}

One of the responsibilities of the Stock exchange is to mobilize savings for investment within an economy. When people draw their savings from banks and invest in stocks, it leads to a more balanced allocation of resources, because money, which could have been consumed or kept in inoperative deposits with banks, are mobilized and redirected to promote commerce and industry.

In view of its importance and nature of job, the stock market also reacts very sensitively to any untoward incident or inadequate policies by its regulators. There are some factors that highly influence the performance of stock market. "Rapidly changing political environments, Internal and external crisis and inadequate government policies are the main factors due to which the stock markets cannot perform effectively, causing huge loss to the national economy" (Shafi, 2000).

\subsection{Review of Theoretical Literature}

Ahmed Viqar and Rashid Ahmed (1986) are of the belief that for balance economic growth of the country, it is very essential to keep a close eye on the performance of stock market.

Amjad Saeed Khawaja, (2008) maintains that like any other financial market, (i.e. Banking sector, money market), the stock market is more sensitive, thus requires more attention and stability.

Arif Mehmood (1985) describes stock market as the basic component for economic growth. He says without this component, the growth remains an unanswered question.

Ishrat Hussain (2003) states in his book, "Economic Management in Pakistan" that economic outcomes are not always under complete control of policy makers. Noneconomic factors, extended environment, and response of private agents do make a lot of difference in the growth and development of a country's economy, in which the 
performance of stock market plays a vital role.

\subsection{Review of Previous Empirical Studies}

In the past, several studies have been carried out on the performance of stock market, its problems and solutions to grow it further, in large extent and the causes of the low growth or negative trend, in some extent.

As far as the limited study of the researcher is concerned, the previous researchers have only been successful in describing terrorism and political instability, the cause of such downturn of the stock markets, and no one has so far described government policies, institutional clashes and terrorism due to inadequate counter terrorism tools as main reason for the downturn of stock market in Pakistan.

\subsection{Study Objectives}

The purpose of the study is to conduct a research on stock market, aiming to explore the causative factors which lead to its downturn, and result into terrible financial loss. In order to get accurate results, following questions have been taken in the study:

1. Why political uncertainty puts negative impacts on performance of stock market?

2. Why terrorist attacks in remote area like Swat, Mangora, Tribal Areas etc. affect the efficiency of stock market in Karachi?

3. Why sustainable government policies are essential for growing stock markets?

4. What tools and techniques are required to keep stock markets grow?

\subsection{Significance of the Study}

According to Hussain Fazal and Mehmood Tariq (2001) the stock markets perform as backbone of any country's economy. Countries greatly depend over capital markets for economic growth and prosperity. The study in hand will be supportive and helpful for policy makers as well as the investors (big and small) to make better future financial decisions and remedies as well.

\subsection{Research Methodology}

The nature of research is qualitative. For primary data, a comprehensive questionnaire is designed covering all the necessary and related questions. The questionnaire has been distributed and duly filled randomly by respondents, which include stock brokers, big and small investors, politicians, law makers and economists. A sample of 150 respondents was selected for this purpose. Whereas the secondary data includes, reports published by State Bank of Pakistan, Economic Survey of Pakistan, various research journals and reports.

\subsubsection{Variables}

Following are the major factors contributing to the decline in the stock markets inPakistan: 
- $\quad$ Political Instability

- $\quad$ Law and order situation/Uncertainty

- Terrorism

- Government Policies

- Brokers' Manipulation

- Global Crises

- Institutional Interactions

\subsection{Limitation of the study}

While working on primary data in the field, the author faced so many problems in getting the required data in Karachi and Quetta as the five year data on political instability and some data on the impact of terrorist activities was unavailable. ( for instance, the difficulty in getting the required data was also because of the law and order situation in both the provincial capitals, Karachi and Quetta). Therefore, I confined myself to the year 2009 in respect of political instability and terrorism.

\subsection{Coverage of the study}

Due to time constraints, two cities, Karachi and Quetta were selected for the research. In Karachi, the largest stock exchange of the country, Karachi Stock Exchange and its 100 index (KSE100) was selected for the purpose, since it is the most recognized index for KSE. This index is used in the research as the proxy for the movement of the stock market.

\subsection{Study Period}

The period of the study in this research is five years (between 2005 -2009), covering all major events during this period. However, the focus of the research will mainly be on three major factors?Political Instability, Global and National Terrorism and Government Policies.

\subsubsection{Profile of Respondents}

- $\quad 25 \%$ respondents are law makers, and economist who are involved in decision making and designing government policies.

- $15 \%$ respondents are politicians, sitting in government as well as on opposition benches, directly or indirectly involved in policy decisions and implementation.

- $60 \%$ respondents are the small and big investors and stock brokers having active involvement in stock business. 


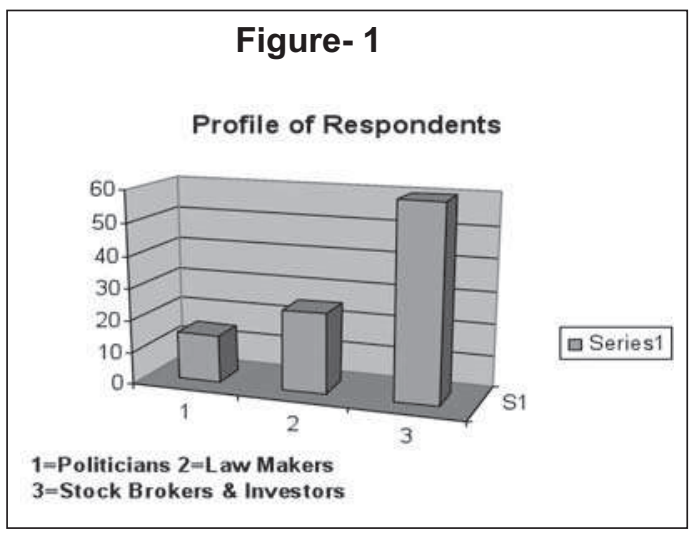

\section{Discussions and Data Analysis}

\subsection{The Role of Political Stability}

Political stability is very important for the economic development of any country. It has an essential part in construction of investor attitude. "Politics and economics are forever intertwined; almost any event can trigger political change" (Akbar Zaidi, 1999).

An unexpected resignation by a leading political figure, a terrorist act, a sudden change in government, or a currency collapse can completely transform the political and economic landscape.

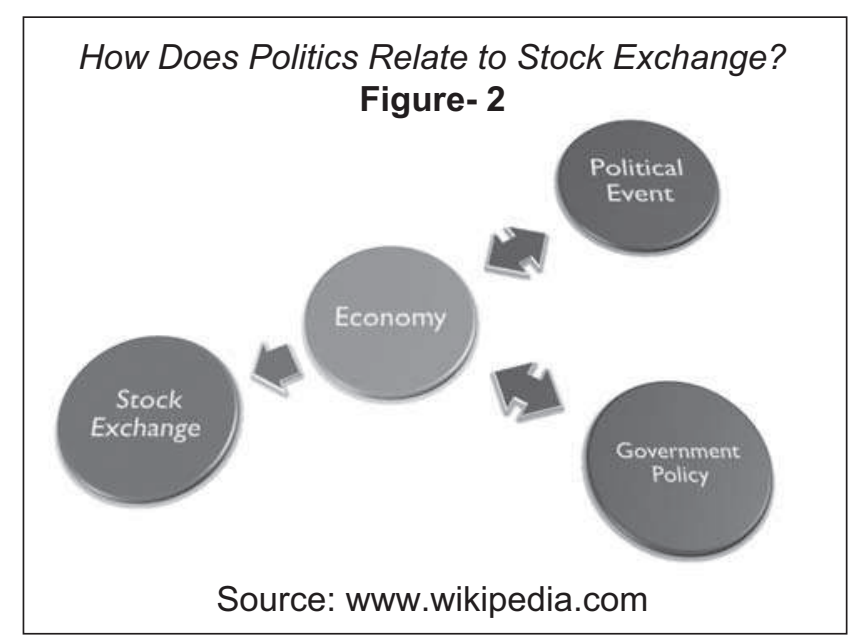

Ali Imran (2001) has very well said that political change in the country puts a significant impact on businesses as well as on individuals. For a business, the political risks associated with political change are multifaceted. For instance, the question of whether the Supreme Court verdict suspending the executive order regarding the appointment of high court and supreme court judges is also followed by the government certainly 
has an implied affect on stock markets. This is because stock exchanges of any country react very sensitively on such news or political changes. Such changes keep the investors pessimistic as they fear of the blockage their savings due to the uncertain condition of the stock market. Simultaneously, when the national investor faces obstacles with political changes, an international investor also faces the risk of loosing assets when a new ruler takes over or an existing government changes its policy towards foreign investment. Political risks are very uncertain for international traders. If you want to export goods to a government buyer and after that you discover that ban has been imposed on that particular country, this will obviously result into financial loss as your investment will be blocked till the ban in lifted. This is how the unusual political movements create hurdles for business people or companies. The other equally important issue is that psychology is highly involved in stock market. A small rumor can spoil the business of millions of dollars, if not controlled in time. In the words of Ali S.H Mubarak (1993) unstable political conditions pose threat to the stock market. The market turns negative and activities remain inactive soon after hearing any sensitive issue or change in political scenario. For instance, the news of the resignation of Finance Minister Shoukat Tarin spread the wave of pessimism in Karachi Stock Exchange on 23-022010, where KSE 100 index went down by 132 points. Likewise, next day, on 24-022010, the index again lost another 137 points, laving the KSE 100 index to close at 9686. The other indices, KSE 30 and KSE All also remainednegative. Table- 1

Downward Movement of KSE-100 Index after the resignation news of Finance Minister

\begin{tabular}{|c|c|c|c|}
\hline Date & Opening Index & Closing Index & Decline \\
\hline $23 / 02 / 2010$ & 9955 & 9823 & 132 \\
\hline $24 / 02 / 2010$ & 9823 & 9686 & 137 \\
\hline \multicolumn{3}{|c|}{ Total Decline } & $\mathbf{2 6 9}$ \\
\hline
\end{tabular}

Source: Author's own

On the other hand, the resignation of former president Pervez Muharraf after more than eight years rule, removed the uncertainty and left a healthy effect on stock market, where market showed growing trend and investors gained confidence. The market gained 4.5 per cent (460 points) on 18/08/2008 on the day he resigned (www.karachistockmarket. blogsome.com). During three days, the market gained 1000 points. These frequent ups and downs do harm the performance of the stock market and discourage local as well as foreign investors to keep themselves out of stock business.

Therefore it is ideal that in order to gain best results out of the financial markets, the political stability may be ensured in the country, without which sustainable growth can not be achieved.

\subsubsection{Institutional Clashes}

The clash between public institutions also affects the performance of the stock market. The recent Executive-Judiciary clash on appointment of judges on February 12, 2010 
resulted in market decline of more than 100 points. The KSE 100 index plunged by 104.06 pints on panic selling triggered by the crisis between the institutes and fears of political polarization.

Table- 2 The status of KSE-100 index before and after the Executive-Judiciary clash.

\begin{tabular}{|c|c|c|}
\hline Before Crisis & After Crisis & Total Decline \\
\hline $12 / 02 / 2010$ & $15 / 02 / 2010$ & \multirow{2}{*}{104.06} \\
\hline 9 & 9701.81 & \\
\hline
\end{tabular}

Source: Author's own

\subsection{Analysis of Political Instability/Rapidly Changing Political Situations}

The analysis of foregoing factors show that $70 \%$ respondents were of the view that rapidly changing political situations were the main cause behind the volatility of stock markets in the country. $20 \%$ quoted other factors like exchange rate variation and manipulation. Whereas rest of the $10 \%$ remained undecided about the real causes.

\section{Figure- 3 Analysis of Rapidly Changing Political Situations}

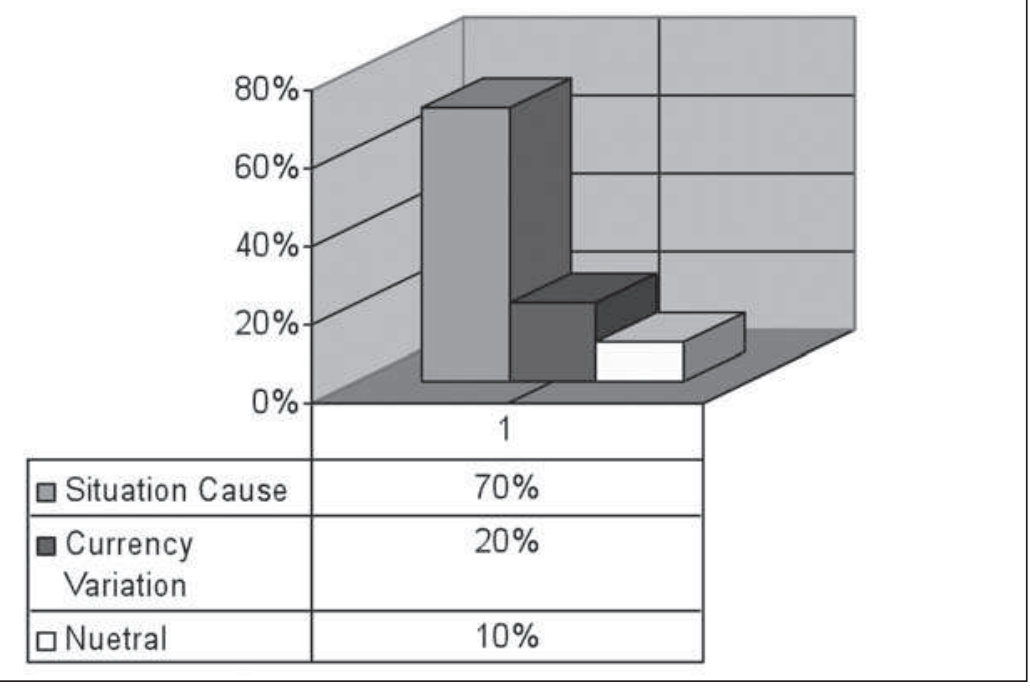

\section{Terrorism and financial crisis in Pakistan}

Any internal crisis is a significant factor that influences the performance of stock markets. These crises, like, terrorism and suicidal attacks, have the potential to affect the economy in the medium term by deflating consumer and investor confidence. A decline of confidence caused by such terrorist activities reduces the motivation for investment. This process can spread through the economy and the rest of the world through normal 
business cycle and trade channels. Similarly, falling investor confidence may cause a widespread drop in asset prices. The level of the effects would depend on a range of factors, including the nature of the attacks, the multiplier effects, the type of policies adopted in response to the attacks, and the resilience of the markets.

\subsection{Terrorism}

"Terrorism is a systematic use of terror which includes acts of unlawful violence and war, targeting innocent people and destroying peace of that particular area/country" (www.chowrangi.com) Terrorism does not only create panic and take away precious human lives, but also terribly damages country's economy. Swat, Waziristan, and Malakand division are the worst examples of terrorism where economy has taken a nose dive in the last decade. Stock market is very sensitive place. A news of terrorist attack in a remote area of a country is very likely to affect the business at Karachi Stock Exchange very badly.

\subsection{The statistics of human loss caused by terrorism from 2005 to 2009.}

\subsubsection{Statistics from 2005 to 2008}

Table- 3 Details of terrorist attacks during 2005-2009

\begin{tabular}{|c|c|c|c|c|}
\hline Year & Total Attacks & Annual Increase & Killed & Injured \\
\hline 2005 & 254 & --- & 216 & 571 \\
\hline 2006 & 675 & $159 \%$ & 907 & 1543 \\
\hline 2007 & 1503 & $129 \%$ & 3448 & 5353 \\
\hline 2008 & 2577 & $43 \%$ & 7997 & 9670 \\
\hline 2009 & 3816 & $48 \%$ & 12632 & 12815 \\
\hline
\end{tabular}

Source: www.san-pips.com, Access date: February 15, 19, 20, 2010.

Table- 4 The Nature of Attacks during 2008

\begin{tabular}{|c|c|c|c|c|}
\hline No. & Attacks/Clashes & No. of Incidents & Killed & Injured \\
\hline 1 & Terrorist attacks & 2148 & 2267 & 4558 \\
\hline 2 & Operational attacks & -- & 3182 & 2267 \\
\hline 3 & $\begin{array}{c}\text { Clashes between Security } \\
\text { forces and Militants }\end{array}$ & 95 & 655 & 557 \\
\hline 4 & Political Violence & 88 & 162 & 419 \\
\hline 5 & Inter-tribal sectarian clashes & 191 & 1336 & 1662 \\
\hline 6 & Border Clashes & 55 & 395 & 207 \\
\hline 7 & Total & & 7997 & 6970 \\
\hline
\end{tabular}

Source: www.san-pips.com, Access date: February 15, 19, 20, 2010. 
The terrorist activities continued throughout the year 2009 creating an increasing sense of insecurity among the people. The horror of terrorism affected both the daily life and the economic activity across the country. Stock markets declined and negative trend continued in capital markets. Following table shows the terrorist attacks and their nature in all the provinces of Pakistan including FATA and Azak Kashmir:

Table- 4 The Nature of Attacks during 2009

\begin{tabular}{|c|c|c|c|c|}
\hline No. & Attacks/Clashes & No. of Incidents & Killed & Injured \\
\hline 1 & Terrorist attacks & 2586 & 3021 & 7334 \\
\hline 2 & Operational attacks & 596 & 6329 & 3181 \\
\hline 3 & Clashes between Security & 209 & 1163 & 780 \\
\hline & forces and Militants & & & \\
\hline 4 & Political Violence & 130 & 210 & 370 \\
\hline 5 & Inter-tribal sectarian clashes & 217 & 1209 & 787 \\
\hline 6 & Border Clashes & 78 & 700 & 363 \\
\hline 7 & Total & $\mathbf{3 8 1 6}$ & $\mathbf{1 2 6 3 2}$ & $\mathbf{1 2 8 1 5}$ \\
\hline
\end{tabular}

Source: www.san-pips.com, Access date: February 15, 19, 20, 2010.

The deteriorating law and order situation, suicide bombing and sectarian violation loses the confidence of the investors in the market. The ongoing terrorist attacks in NWFP and the recent suicide attacks in Karachi had brought the Index down as investors feared to invest their capital due to the uncertain conditions.

In the opinion of Aslam Pervez Abro (2010), one of the reasons behind the increasing number of terrorist attacks and Pakistan's inability to counter it, is the lack of modern technologies and intelligence equipment to probe the suicide attacks. On operational level, government needs to improve the capabilities in counter measures involving hard and dedicated work by intelligence services to unearth the networks of suicide bombers in tribal areas and mainland Pakistan.

\subsection{The Financial Crunch}

The March 2005 stock market Crash* is another example of internal crisis caused by the stock brokers itself. That crash at Karachi Stock Exchange and Lahore Stock Exchange took away around \$13 Billions. A Stock Market crash is sudden dramatic decline of the share prices in the stock market. Such crashes are driven by underlying economic factors. They often follow speculative stock market bubbles. Stock market crashed are social phenomena where sometimes external economic events also matter. Among the losers most of the people were small investors who could not survive this biggest loss. The stock market fall of 2005 was so sudden and unpredictable that within 
two weeks (March 14, 2005 to March 28, 2005) most of the stocks lost their values by fifty (50) percent.

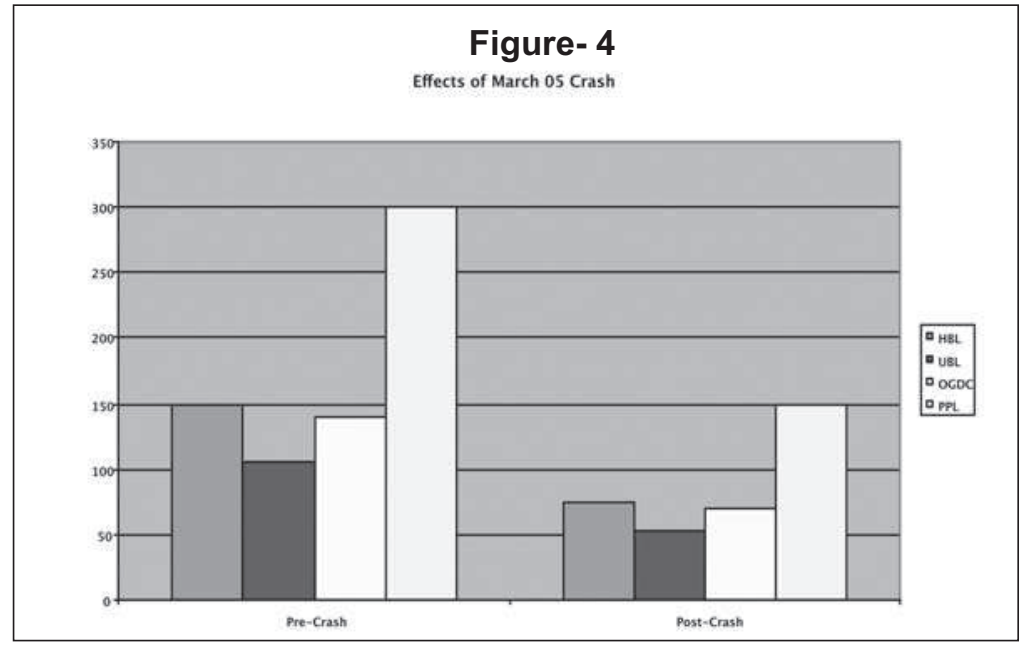

\subsection{Analysis of Terrorism and Financial Crises in Pakistan}

Among the sample size, $80 \%$ respondents said terrorism was the major reason of the instable and fragile capital markets in Pakistan. While the remaining $20 \%$ termed other factors responsible.

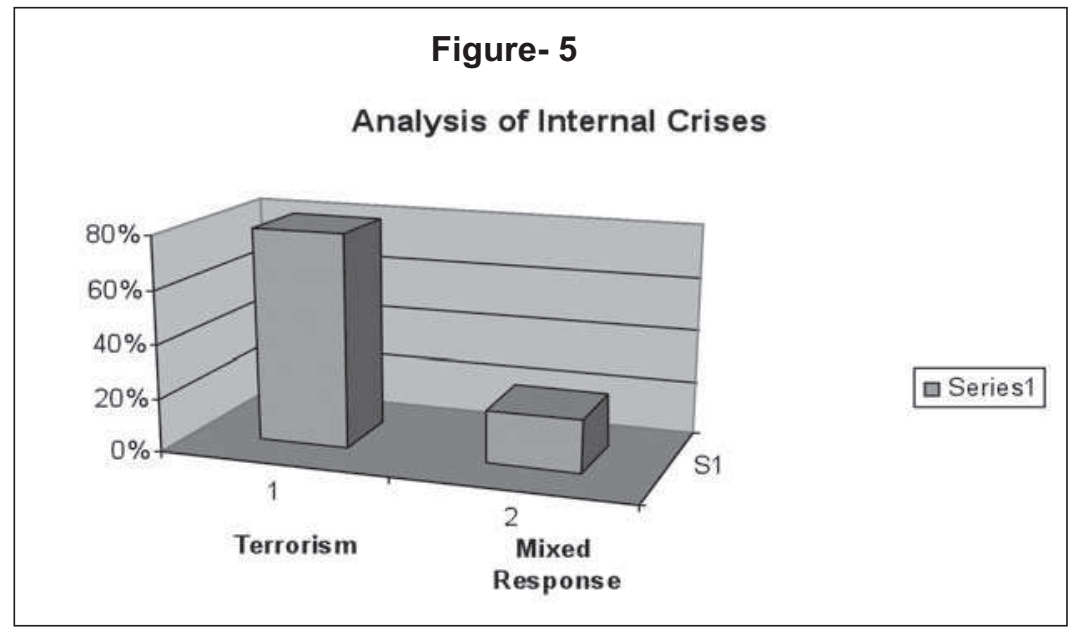

\section{Global Crisis}

\subsection{Global Terrorism}

Like the internal uncertainty, the global crisis is also one of the reasons that put the stock markets towards negative zone. The September 11 attacks are the glaring example of global economic terrorism. The 9/11 attacks primarily affected the major industrial countries through a fall in demand generated by the loss in confidence about the 
economy and its impact on output. Emerging markets were affected by slowing external demand and a flight in financial capital. Other developing countries may have been affected through commodity markets.

In South Asian region_Pakistan, India, Afghanistan, Nepal, Sri Lanka and Indian Occupied Jammu and Kashmir_23098 people were killed during 2008 in terrorism and violent conflicts. More than one third 7997 (35\% of the total) ñ were killed in Pakistan alone. However, Sri Lanka remained on the top with 8515 (37\%) killings followed by Pakistan and then Afghanistan with 5209 (23\%) killings, as the following table shows.

Table-6

\begin{tabular}{|c|c|c|c|}
\hline No. & Country Name & Killings & \%age of South Asia Region \\
\hline 01 & Sri Lanka & 8515 & $37 \%$ \\
\hline 02 & Pakistan & 7997 & $35 \%$ \\
\hline 03 & Afghanistan & 5209 & $23 \%$ \\
\hline 04 & India and Kashmir & 1250 & $05 \%$ \\
\hline 05 & Nepal & 127 & $01 \%$ \\
\hline
\end{tabular}

Source: Pakistan Security Report 2008, www.san-pips.com, Access date: February,20, 22, 2010 .

\subsection{Global Financial Crises}

When recession comes it does not remain confine to one country. It crosses borders and affects other economies as well. The global financial crisis 2009 badly affected the world economies and put the emerging economies like Pakistan in a huge shock. The fall of financial giants like AIG and heavy bailout of $\$ 700$ billion by USA generated worst impact on the emerging economies.

The recent financial market downturn in Dubai has also made the local investors very pessimistic. The fall of an advanced economic center like Dubai definitely influence the sentiments of the investors in neighboring countries like China, India, Pakistan etc.

\subsection{Analysis of Global Crises}

A moderate response was observed while analyzing the foregoing factor. $40 \%$ respondents out of the universe held global crises responsible for instability of stock markets. $30 \%$ quoted other factors, $20 \%$ termed the government policies responsible, while $10 \%$ remained uncertain and thus silent. 


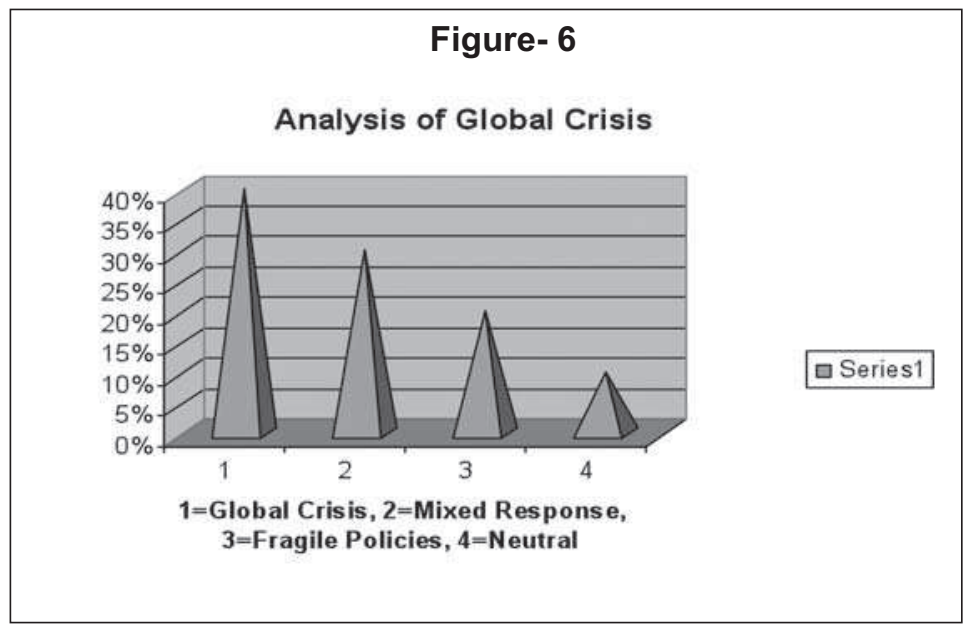

\section{Government Policies}

Sometimes, the trends of the stock markets also drive the measures taken by the government. Some forecasters treat the stock market as intensity for the performance of a government on various financial fronts. Government of any country is believed to be the guiding principle/policy designer. The guideline provided by the government, decide the potential for business.

The annual budget proposes changes in taxes, changes of government policy in sectors, and budgetary and other allocations for ministries. This drives the prospects of growth in various sectors and stocks. Government policies can impact any industry - telecom, energy, oil and gas, refinery, banking, transportation, organized retail, import/export scenario etc.

The government is also a major consumer in a country. Government spending in any sector can provide thrust to that sector. There are many industries that are dependent on government policies or government spending. Since different political parties have different agenda and views, it becomes important for

investors to interpret them and invest in stocks that are in a favorable position. Some examples of sectors that are affected by government decisions include Infrastructure, Automobile sector, Banking Sector, Public Sector etc.

\subsection{Policies that can affect the Stock Market performance}

\subsubsection{Fiscal Policy}

\subsubsection{Capital Gain Tax}

The levy of capital gain tax on short term investments, on the one hand, encourages 
the long term investment. But, on the other hand, terribly disappoint the short term investors. The announcement of the said tax has left most of the short termand medium term investors in the shock, creating obstacle in the stock business.

\subsubsection{Monetary Policy}

\subsubsection{Discount Rate}

Stabilized monetary policy boosts the economy as people get loans and invest in the market in different forms. This way, the circulation of money takes place. While tightened monetary policy with increased discount rate lessens the investment. This reduces credit money as well as the investors' interest in the business, resulting into decline in stock market performance. Likewise, the expectation of the cut in discount rate accelerates the stock market pulse.

In November 2009, the rumors to cut down the discount rate by the SBP raised the expectations of the investors, which ultimately put a positive impact on the Karachi Stock Exchange during the week ending on November 20, 2009.

Table- 7 KSE-100 Index during November 16 to 20, 2009

\begin{tabular}{|c|c|c|}
\hline Before Expectation & After Expectation & Total Gain \\
339.19
\end{tabular}

\subsection{Analysis of government policies}

Majority of respondents (60\%) viewed government policies responsible for the crisscross financial path of the capital markets. They stated that sound and sustainable policies by the government can lead the stock markets to the persistent growth. $30 \%$ respondents termed the big investors and brokers responsible while the rest of $10 \%$ remained undecided.

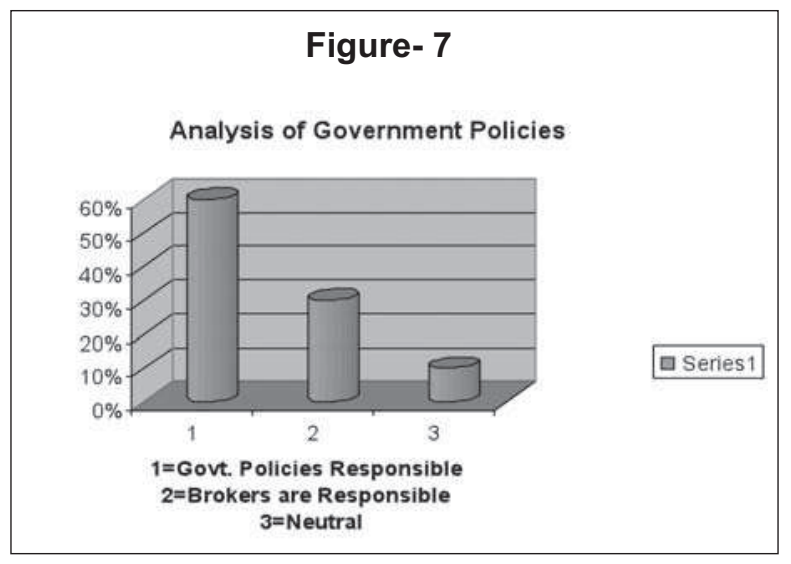




\section{Key Findings}

- $\quad$ The anal ysis has proved that all the factors mentioned are not equally responsible for the fall of stock markets in Pakistan.

- $\quad$ The study showed that terrorism is the leading factor which discourages smooth economic activities in capital markets and creates fear amongst local and foreign investors as well.

- $\quad$ Counter-terrorism tools such as technology and human intelligence are not sufficient to curb the terrorism from the country. Previous studies indicate that only political instability and terrorism affect the stock market performance, while this research has proved that frequently changing government policies, institutional clashes and lack of counter terrorism tools also effect the performance.

- The factor that stands at 2nd position is the sudden changes in political scenario of the country.

- $\quad$ According to the response of the target population, the global crisis is the least factor causing damage to the capital markets comparatively.

\section{Conclusion}

Stock market is a major contributor to national exchequer. It attracts both national and foreign investors by its continual upward trends and investment opportunities. The present research has concluded that stock market plays an important role in the economy by mobilizing resources and channeling them to productive investment. The companies' growth largely depends on the development of the capital market. The research also explored that the main causes which badly affect the growth and performance of the stock markets are: the unstable political conditions; Internal and external crisis (i.e. terrorist activities) and inadequate government policies. The research concluded that in order to gain best results all the foregoing factors should be controlled properly within the country, without which sustainable growth can not be achieved.

\section{Recommendations}

1. Long term policies must be designed and implemented by the government to ensure sustainable and uninterrupted growth of the stock markets. This will not only influence the high performance, but will also attract the foreign investors.

2. Strict vigilance and follow-ups by the government are required for the best results of stock market.

3. Tight security measures should be applied to curb the deteriorating law and order situation prevailing in the country. This can be done through collective efforts of the Government, its affiliated agencies and the opposition parties as well.

4. All parties' conference may be called and solution must be sought to eliminate the menace of terrorism from within the country.

5. Programs may be arranged in different countries, particularly recently affected economies (Dubai in recent case) and foreign investments should be attracted/invited in the country.

6. Investment friendly policies may be designed to encourage and attract domestic and foreign investments. 
7. The role of SECP may be strengthened to regulate stock markets and guide those markets in the larger interest of the country.

8. The top management of stock exchanges and its regulators (SECP) should arrange awareness programs at district level to attract the investments.

9. The scientific research should be carried out to find out the cause of terrorism and then the measures to be adopted to curb it.

10. A comprehensive multi-layered long term strategy should be formulated to root out the causes of terrorism.

11. New technology/equipment should be introduced/brought forward for counterterrorism activities in the country and affected areas are to be cleansed of this threat. 


\section{References}

Ahmad, Viqar and Rashid Amjad. (1986) "The Management of Pakistan's Economy", 1947-82. Karachi: Oxford University Press.

Ali, Imran. 2001b. 'Business and Power in Pakistan', in A.M. Weiss and S.Z.Gilani (eds), Power and Civil Society in Pakistan. Karachi: Oxford University Press.

Ali S.H Mubarak (1993) "An Analytical Approach to the economy of Pakistan". Rehbar Publishers, Karachi Pakistan.

Amjad Saeed Khawaja (Nov. 2005) "Statistical Analysis- Karachi Stock Exchange". Hailey College of Banking and Finance, University of Punjab.

Amjad Saeed Khawaja, (2008) "Economy of Pakistan". Khawaja Saeed, 230-C, TECH Society, Canal Bank Road, Lahore

Arif Muhammad (1985) "Economics of Growth and Basic Needs in Pakistan". Progressive publishers, Lahore.

Aslam Pervez Abro, "Intelligence Reforms" Article, Dawn, February, 02, 2010

E. Victor Morgon and W.A Thomas (2003) "The Stock Exchange- Its History and Functions". Elek Books, Great James Street, London.

"Economic survey of Pakistan" (2003/2004) Ministry of finance, Government of Pakistan.

Hussain Fazal, Mehmood Tariq, (2001) "The Stock Market and the Economy in Pakistan". Pakistan Development Review, PIDE, Islamabad.

Ishrat Hussain (2003) "Economic management in Pakistan 1999-2002", Oxford University Press, Karachi.

Dawn report (2005) Pakistanis Riot as shares Plunge, Dawn March 24, 2005, an article by AFP. S. Akbar Zaidi, (1999) "Issues in Pakistan economy" (Oxford University Press, Karachi). Khan Shafi, (2000) 50 years of Pakistan Economy, Oxford Press, Karachi). Dawn report (2005) protecting small Investors, Dawn report, April 5, 2005). www.global issues.org, accessed on February 19, 2010. www.san-pips.com, accessed on February 19, 20, 22, 2010. www.Kse.com.pk, accesed on January 18, February 05, March 01, 2010. www.chwrangi.com, accesed on February 05, 06, 2010 